\title{
Neuroprotective Effect of Bauhinia variegata Leaf Extract against Colchicine: An Experimental Study on Cognitive Dysfunction and Biochemical Alterations in Mice
}

\author{
Pragati Khare ${ }^{1, *}$, Kamal Kishore ${ }^{2}$, Dinesh Kumar Sharma ${ }^{3}$ \\ ${ }^{1}$ Department of Pharmacy, Shri Ram Murti Smarak, C.E.T., Bareilly, Uttar Pradesh, INDIA. \\ ${ }^{2}$ Department of Pharmacy, M.J.P. Rohilkhand University, Bareilly, Uttar Pradesh, INDIA. \\ ${ }^{3}$ Department of Pharmacy, Himalayan Institute of Pharmacy and Research, Dehradun, Uttarakhand, INDIA.
}

\begin{abstract}
Objectives: To study the protective role of Bauhinia variegata ethanolic leaf extract induced by colchicine cognitive dysfunction and the damage of oxidative in Swiss albino mice; to examine the neuroprotective consequence of Bauhinia variegata by conducting behavioral memory tests and to estimate the biochemical parameters by using brain homogenate. Methods: The research was conducted on colchicine induced model for a period of 28 days (4 weeks). Behavioral research was conducted using Elevated plus maze, Passive evasion Paradigm, Morris water maze and Actophotometer; thus biochemical parameters of brain homogenate such as acetyl cholinesterase (AChE), total protein, lipid peroxidation (MDA) and glutathione (GSH) were estimated. Swiss albino mice (48) were distributed into eight sets, each constituting 6 mice. Class I got carboxy methyl cellulose 1 per cent w/v. Group II piracetam was administered i.p. (200 milligrams / kg). Group III obtained $1 \mathrm{mg} / \mathrm{kg}$ of colchicine i.c.v. Group IV and V were provided with 200 and $400 \mathrm{mg} / \mathrm{kg}$ of ethanolic Bauhinia variegata leaf extract. Group VI was administered Piracetam (200 mg / kg, i.p.) to mice each day for 28 days continuously. Colchicine $1 \mathrm{mg} / \mathrm{kg}$, i.p., at $60 \mathrm{~min}$ after $28^{\text {th }}$ day piracetam injection was injected. Group VII and VIII received 200 and $400 \mathrm{mg} / \mathrm{kg}$ oral ethanolic Bauhinia variegata leaf extract for 28 consecutive days, and colchicine $(1 \mathrm{mg} / \mathrm{kg})$ was injected i.c.v at $90 \mathrm{~min}$ after extract administration on the $28^{\text {th }}$ day. All the data and information were examined and analyzed through the use of ANOVA which is One-way then by a check by Tukey's test. Results: The Bauhinia variegata leaf extract showed substantial reduction in raised plus maze and morris water maze transfer latency. It showed a marked increase in passive avoidance paradigm transfer latency. The administration of ethanolic Bauhinia variegata leaf extract $(200 \mathrm{mg} / \mathrm{kg}$ and $400 \mathrm{mg} / \mathrm{kg})$ indicated a substantial increase $(P<0.001)$ in acetylcholinesterase and GSH levels, a significant reduction $(P<0.001)$ in total protein, $\mathrm{NO}$ and MDA. Conclusion: This study shows ethanolic leaf extract of Bauhinia variegata has a neuroprotective effect against memory loss caused by colchicine.
\end{abstract}

Key words: Bauhinia variegata, Neuroprotective, Alzheimer's disease, Colchicine.

\section{INTRODUCTION}

The disease of Alzheimer is a chronic and liberal neurological condition that slowly causes loss of memory, behavior change, personality and ability to think. Dementia in older people is primarily caused by Alzheimer's disease. Duration between symptom initiation and death takes about
8.5 years. Approximately 15 million world population suffer from Alzheimer's disease. ${ }^{1}$ The disease of Alzheimer characteristically affects folks around age 65 years. $^{2}$ More free radical generation mostly damages the central nervous system. The excessive formation of free radicals can lead to neuronal
Submission Date: 07-09-2020; Revision Date: 07-03-2021; Accepted Date: 29-08-2021

DOI: 10.5530/ijper.55.3s.187 Correspondence: Mrs. Pragati Khare, Department of Pharmacy, Shri Ram Murti Smarak, C.E.T., Bareilly, Uttar Pradesh, INDIA. Phone: +91-07310753079, Email - pragatikhare10@ gmail.com

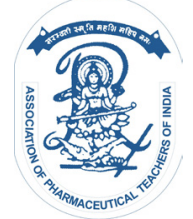

www.ijper.org 
destruction to DNA, membrane lipids and proteins. There is a marked decline of cholinergic neurotransmission in elderly people due to decreased levels of acetylcholine in the brain. ${ }^{3}$ The most important cause of dementia is Alzheimer's disease (AD) where neuron loss occurs in distinct areas of the brain. ${ }^{4} \mathrm{AD}$ is characterized by neurotic plaque formation that includes amyloid $\beta$ protein. Cholinergic cell failure occurs in the forebrain and acetylcholine that is responsible for the development of dementia. ${ }^{5}$ Pollutants, stress and hereditary predilection are the key risk factors for neurodegenerative disorders. ${ }^{6}$ The conventional medicine is commonly used for the deterrence and prevention, diagnosis and management and treatment of various ailment and diseases. The treatment by herbal plants of different diseases depends on observations and previous experiences found in books or taught verbally. ${ }^{7}$ Neuroprotection involves the therapeutic strategies which can delay or cure neuronal damage. Nowadays, herbalism is as reliable, healthy and cheaper as it is in trend. ${ }^{8}$

Baubinia variegata named Mountain Ebony (English), Rakta kanchan (Marathi), Kachnar (Hindi) belongs to the family Leguminosae (Caesalpinioideae). It is a medium-sized, tree which seasonally shed its leaves found in Himalayas, at an altitude of $1800 \mathrm{~m}$ across India. Leaves are curved at apex, connate for about two-thirds up, wider, leaflets are ovate firmly sub-coriaceous, pubescent beneath when young and intensely cordate with two leaflets. Flowers are distinctive in colour, lateral, sessile, stamens 5 , absence of staminodes, flat fruits; rough glabrous dehiscent seeds, seeded 10-15. ${ }^{9}$ It is growing in all of India and China. It is a reliable kind of greenhouse that grows in the Himalayas at an altitude of $1800 \mathrm{~m} .{ }^{10}$ Baubinia variegata Linn. is customarily used in ulcer bronchitis, intestinal worms, fungal infection, diarrhea, dysentery, hepatic disorders, diarrhoea, leprosy, skin disease, wounds, bacterial infection and tumors. ${ }^{11,12}$

\section{METHODS AND MATERIALS}

\section{The material of plant}

Baubinia variegata leaves were picked and collected from Shri Ram Murti Smarak college campus and identified by Prof. A.K. Jaitly, The plant science department. A voucher specimen (specimen number- RU/PS/2016/415) of the gathered sample has been deposited for future reference in the institutional herbarium.

\section{Extracts preparation}

The Baubinia variegata leaves were initially washed in tap water, followed by drying in shade and finally powdered.
The powder obtained was stored and packed into the column of Soxhlet and extracted for $24 \mathrm{~h}$ using petroleum ether $\left(60-80^{\circ} \mathrm{C}\right)$. The obtained marc was extracted sequentially with chloroform $\left(50-60^{\circ} \mathrm{C}\right)$ followed by ethanol extraction $\left(68-78^{\circ} \mathrm{C}\right)$ for $24 \mathrm{~h}$. The extract was collected was concentrated on a water bath at $50^{\circ} \mathrm{C}$. The extracted dry powder was kept at room temperature. The harvest of the extract of petroleum, chloroform extract, methanol extract, ethanol extract and water extract was found to be 9.50 percentile (w/w), 7.65 percentile $(w / w), 8.95$ percentile $(w / w), 8.50$ percentile $(\mathrm{w} / \mathrm{w})$ and 0.30 percentile $(\mathrm{w} / \mathrm{w})$. Throughout the experimental analysis the ethanolic leaf extract was used.

\section{Drug Treatment}

The test of pharmacological made the extract obtained to be suspended at doses of 200, $400 \mathrm{mg} / \mathrm{kg}$ p.o. distilled water which double comprises carboxy methyl cellulose ( 1 percent w/v CMC). The prescriptions and dosages were administered to every mouse in sets and group 4,5,7,8 based on earlier researches of the ethanolic extract of Baubinia variegata extract. $U p$ to the end of the study period there was no mortality due to medication. During the course of the treatment, the drug excerpt and extract of Baubinia variegata caused no abnormality or death.

\section{Animals}

Animals were collected from Animal House, Pharmacy Department, SRMS CET (Pharmacy), Bareilly, U.P. Animals were approved for this study by the Institutional committee responsible for Animal Ethics of the Pharmacy Department, SRMS CET (Pharmacy), Bareilly, U.P. Approval number (715/PO/Re/S/02 / CPCSEA). Swiss albino strains of undeveloped healthy adult mice of both sexes in equivalent numerical for every group $(n=6)$ were taken for the study. The weight differences of the used animals were kept nominal at the start of the research and did not exceed \pm 20 per cent of the average weight of each and every species. Mice usually weighed 25-30 gm.

The experimental animal house temperature of $22^{\circ} \mathrm{C}$ was maintained. Relative humidity must be between ranges from 50 to $60 \%$. The lighting was artificial; the sequence was 12 light hr, 12 dark hr. We used traditional laboratory diets ad libitum provided with drinking water. Animals of the same group had been kept together in one cage. Healthy young adult mice were indiscriminately assigned to the control, standard and treatment sets and group. The animals were marked by labeling at the base of the tail and accustomed in their cages for at least 5 days before the research was initiated. 


\section{Chemicals and Drugs}

Drugs: Sigma Aldrich had purchased piracetam and colchicine.

Chemicals: Ethyl acetate, petroleum ether, methanol, ethanol and chloroform were got from the laboratory of Central Drug House.

\section{Vehicle}

Baubinia variegata extract (BVE) has been suspended in $1 \% \mathrm{w} / \mathrm{v}$ CMC and administered through oral means to mice. Colchicine and Piracetam were liquefied distinctly in normal saline and injected i.c.v. and i.p. respectively. The Capacity administered orally and i.p. injection was $1 \mathrm{ml} / 100 \mathrm{~g}$ of mouse.

\section{Studies with serious toxicity}

Baubinia variegata ethanolic extract has been tested for severe oral toxicity in compliance with revised OECD guidelines No. 425 . When given by oral route in dosages of up to $2000 \mathrm{mg} / \mathrm{kg}$, the extract was without any toxicity in mice. Therefore, the experiment used 200 and $400 \mathrm{mg} / \mathrm{kg}$ of ethanolic leaf extract.

Group I: It was a control set. The vehicle was orally administered for 28 successive days and the transferal of latency was assessed on 28th and again on 29th day after 90 min of administration.

Group II: It denoted the positive control set. Piracetam was given to the underdeveloped mice for 28 consecutive days, and transferal of latency was calculated and on 28th day after $60 \mathrm{~min}$ of administration, and again on 29th day after $24 \mathrm{hr}$.

Class III: This was a negative control group. Colchicine was injected i.c.v to underdeveloped mice, and latency transferal being was assessed $45 \mathrm{~min}$ after inoculation and also again after $24 \mathrm{hr}$ (i.e. on the $29^{\text {th }}$ ).

Class IV and V: BVE was orally given to the underdeveloped mice for 28 successive days. TL was reported on 28th day after 90 min of exposure and similarly after a period of $24 \mathrm{hr}$ on the $29^{\text {th }}$ day.

Group VI: Young mice received inoculation of piracetam for 28 successive days. Colchicine $1 \mathrm{mg} / \mathrm{kg}$, i.p., at $60 \mathrm{~min}$ after $28^{\text {th }}$ day piracetam injection was given in. TL was reported after $45 \mathrm{~min}$ of colchicine administration and once more on the $29^{\text {th }}$ day after $24 \mathrm{hr}$.

Group VII, VIII: BVE were orally given to the underdeveloped mice for 28 consecutive days and colchicine $(1 \mathrm{mg} / \mathrm{kg})$ was inoculated i.p. to small aged mice at 90 min. after ad-ministration of excerpt on day $28^{\text {th }}$. TL was reported $45 \mathrm{~min}$. once the inoculation is done and after $24 \mathrm{~h}$.

\section{Behavioral Models which are Exteroceptive Elevated plus maze}

The structure consists of a $10 \times 10 \mathrm{~cm}$-sized central platform attached to two $50 \times 10 \mathrm{~cm}$ open arms and two $50 \times 40 \times 10 \mathrm{~cm}$-sized closed arms and raised $50 \mathrm{~cm}$ above the floor. The research was using mice weighing 20 to $25 \mathrm{~g}$. The experiment was carried out in 2 steps. On day 14 , the day of acquisition testing, each rat was fixed at last position of an open arm pointing away from the middle point. The period of time consumed to through only one locked arms was noted and documented then later calculated as transferal latency [TL]. All four legs were counted as entry within the closed arm. For each mouse the cut-off time was $180 \mathrm{~s}$. Animals who did not reach the closed arms during the time of cut-off were excluded from analysis. Retention testing was carried out on the $15^{\text {th }}$ day, and transfer latency was reported in the same manner as previously stated. Shortening of transfer latency depicted improvement of memory. ${ }^{6}$

\section{Step through Passive avoidance paradigm}

The long term memory was tested using the passive avoidance model. This apparatus was composed of a small chamber connected through a guillotine door to a larger chamber. The smaller chamber, as it was illuminated with a $7 \mathrm{~W} / 12 \mathrm{~V}$ bulb, was also called light chamber. Mice were initially given acquisition trial and subsequently given retention trial after $24 \mathrm{hr}$ followed by IInd, III ${ }^{\mathrm{rd}}$ and IV retention trials on successive days. In the acquirement test experiment, each mouse was positioned at a maximum distance from the guillotine door in the smaller room. We have noticed the time span the mouse had taken to reach the darker room. For the study, the mice which did not reach the door within a cut-off period (90s) were not used. The door was shut automatically after the mouse come into the dark section and an unavoidable foot shock of $1 \mathrm{~mA}$ for $1 \mathrm{sec}$ was recorded. Within 10s the mouse had been detached from the dark room. This procedure has been replicated with standard, control and test drugs. The rise in latency step-by - step was considered as learning. ${ }^{13}$

\section{Morris water maze}

The MWM was utilized for assessing rodent spatial memory and learning. It consists of a large round black container with a thickness of $120 \mathrm{~cm}, 50 \mathrm{~cm}$ height, filled with water at $26 \pm 2^{\circ} \mathrm{C}$ up to a deepness of $30 \mathrm{~cm}$. The spherical pond was separated into four equal quadrants and an $8 \mathrm{~cm}^{2}$ platform was flooded $1 \mathrm{~cm}$ underneath the impervious and opaque surface of one of the quadrants in the middle. The platform's position was held steady throughout the mission. To hide the 
position of the flooded platform the water was made colored which are non-toxic.

The mice were released one by one inside the water and permitted to find the platform for $120 \mathrm{sec}$. Animals were exposed to 2 testing a day for 4 days with an inter-trial period of $20 \mathrm{~min}$, and the time latency to locate the target was low $(<10 \mathrm{sec})$. During through trial mice's escape latencies were registered. The mean of the parameter was done for each and every period of testing and for every rat. When the platform was found by the mouse it was permitted to be on it for $10 \mathrm{sec}$. If the mouse didn't trace the platform within $90 \mathrm{sec}$, it was positioned for $10 \mathrm{sec}$ on the platform and detached from the pool afterwards. Mice were initially given acquisition trial and were given retention trial after $24 \mathrm{hr}$ followed by IInd and III retention trials on successive days. Day by day in trial 1 the decrease in escape latency denotes long-standing reminiscence or reference recollection, while that from testing or trial 1 to trial 2 and 3 represents working memory or shortlived reminiscence. ${ }^{14,15}$

\section{Actophotometer}

Actophotometer comprises six built in photo-sensors and 4 optical counters showing the operation of the locomotive activity. It indicated the behavior digitally. Most locomotive movements in man and animals are affected by CNS acting drugs. The locomotive activity (horizontal activity) can be measured easily by an actophotometer that functions on photoelectric cells that are linked to a counter in circuit. When the beam is cut off by animal of light falling on the photo cell, a count is registered. An actophotometer may possess either a round or a square region where the animal roam about.

We initially weighed and numbered the mice, then switched on the equipment and placed each and every mouse in the activity birdcage individually for $10 \mathrm{~min}$. We noted down all the animals basal activity score. ${ }^{16}$

\section{Biochemical Analysis}

On the $28^{\text {th }}$ day after Colchicine injection the biochemical parameters for oxidative stress such as NO, GSH, MDA and $\mathrm{AChE}$ were calculated in mouse's brain.

\section{Brain tissue preparation}

Using ether anaesthesia the mice were killed. After the cranium was cut and the brain was removed. The brain was cleansed using regular (chilled) saline solution. 10 percent $(\mathrm{w} / \mathrm{v})$ homogeneous brain sample was obtained with $0.03 \mathrm{M}$ sodium phosphate buffer ( $\mathrm{pH}$ 7.4) at 10 strokes at $2000 \mathrm{rpm}$. NO, GSH, MDA and AChE may be measured using a homogenized preparation of brain tissue.

\section{Scavenging activity of Nitric oxide}

Marcocci et al., 1994 coined away of probing nitric oxide searching behavior using Griess reagent using the method. $2 \mathrm{ml}$ of sodium nitropruside is dissolved in $0.5 \mathrm{ml}$ of phosphate of $\mathrm{pH} 7.4$ which was combined with $0.5 \mathrm{ml}$ of extracts of varying concentrations $(50-200 \mu \mathrm{g} / \mathrm{mL})$. The blend was nurtured and incubated for $150 \mathrm{~min}$ at $25^{\circ} \mathrm{C}$. Instead, $0.5 \mathrm{~mL}$ of the hatched solution was mixed at room temperature for $5 \mathrm{~min}$ with $1 \mathrm{~mL}$ of Naphthylethylenediamine dichloride (0.1 percent $\mathrm{w} / \mathrm{v}$ ) with $0.5 \mathrm{~mL}$ of Griess reagent [ $(1.0 \mathrm{~mL}$ of sulfanilic acid reagent $(0.33$ percent of 20 percent glacial acetic acid)]. The mix was then hatched at the surrounding temperature for $30 \mathrm{~min}$ and its absorption was taken at $546 \mathrm{~nm}$. By following this equation the inhibition percentile of Nitric Oxide was found as follows:

NO radical percentile inhibition $=\left(A_{0}-A_{1}\right) / A 0 \times 100$ where

$A_{0}$ - absorbance before reaction

$A_{1}$ - the absorbance after reaction ${ }^{17}$

\section{MDA Measurement}

MDA is a test of peroxidation of the lipids. MDA can be measured spectrophotometrically using standard 1,1,1,3,3-tetraethoxypropane, using the technique defined by Colado et al., 1997. MDA is typically articulated by nanomoles per mg protein. For $10 \mathrm{~min}$ homogenized brain tissue was centrifuged at $700 \mathrm{~g}$. Approximately $500 \mu \mathrm{l}$ of homogeneous brain tissue in phosphate buffer ( $\mathrm{pH} 7.4$ ) was added to $300 \mu \mathrm{l} 30 \%$ trichloroacetic acid (TCA), $150 \mu \mathrm{l} 5 \mathrm{~N} \mathrm{HCl}$, and $300 \mu \mathrm{l} 2 \%$ (w / v) 2-thiobarbituric acid (TBA), respectively. The mix was then boiled at $90^{\circ} \mathrm{C}$ for $15 \mathrm{~min}$ by placing aluminum foil in the mouth of the test tube. The tubes were withdrawn after $30 \mathrm{~min}$ and held in ice-cold water for $30 \mathrm{~min}$. The supernatant was obtained in pink colour. The 12,000g mixture was centrifuged for $10 \mathrm{~min}$, the resultant supernatant was spectrophotometrically calculated at $532 \mathrm{~nm} .{ }^{18}$

\section{GSH Measurement}

GSH was calculated by its 5, 5'-dithiobis (2-nitrobenzoic acid) reaction (Ellman, 1959) yielding a yellow chromophore that was analyzed spectrophotometrically. GSH is a protein expressed in $\mu \mathrm{g} / \mathrm{mg}$. For $10 \mathrm{~min}$ homogenized brain tissue was centrifuged at 700 g. $500 \mu \mathrm{l}$ of brain homogenate was combined with $10 \%$ trichloroacetic acid $(500 \mu \mathrm{l})$ and then centrifuged for protein separation 
at $2000 \mathrm{~g}$ for $10 \mathrm{~min}$ at $4^{\circ} \mathrm{C} .100 \mu \mathrm{l}$ of supernatant was added to $2 \mathrm{ml}$ of $0.1 \mathrm{M}$ phosphate buffer ( $\mathrm{pH} 7.4$ ), $0.5 \mathrm{ml}$ of 5, 5-dithiobis (2-nitrobenzoic acid) (DTNB) and $0.4 \mathrm{ml}$ of deionized water, followed by shaking the mixture onto the vortex. The absorption was taken within $15 \mathrm{~min}$, at $412 \mathrm{~nm}^{19}$

\section{Acetylcholinesterase (AChE) activity}

Acetylcholinesterase action is considered as a marker for the brain's prolonged depletion of the cholinergic system of brain. The Ellman's test conducted quantitative analysis of the acetylcholinesterase levels in the brain. $0.1 \mathrm{ml}$ of DTNB, $0.1 \mathrm{ml}$ of acetylthiocholine iodide, $0.05 \mathrm{ml}$ of supernatant and $3 \mathrm{ml}$ of $0.01 \mathrm{M}$ sodium phosphate buffer $(\mathrm{pH}$ 8) were taken using this process. The absorbance shift at $412 \mathrm{~nm}$ was assessed at a $30 \mathrm{~s}$ interval for $2 \mathrm{~min}$. Outcomes got calculated through the utilization of the chromophore's molar extinction coefficient $\left(1.36 \times 10^{4} \mathrm{M}^{-1} \mathrm{~cm}^{-1}\right)$ and expressed as acetylcholine hydrolyzed / min / $\mathrm{mg}$ protein micromoles. ${ }^{20}$

$$
\mathrm{R}=\frac{\delta \mathrm{OD} \times \text { Volume of Assay } \times 1000}{\mathrm{E} \times \mathrm{mg} \text { protein }}
$$

Where, $\mathrm{R}$ is the rate of enzymatic action in 'micro' mole of acetylthiocholine iodide hydrolyzed per minute per $\mathrm{mg}$ of protein.

$\delta \mathrm{OD}$ is the variation or change in absorbance per minute $\mathrm{E}$ is the coefficient of extinction $\left(1.36 \times 10^{4} \mathrm{M}^{-1} \mathrm{~cm}^{-1}\right) \cdot{ }^{21,22}$

\section{Protein estimation}

In all brain samples, protein was calculated utilizing Lowry's technique where bovine serum albumin (BSA) $(1 \mathrm{mg} / \mathrm{ml})$ was used as standard. ${ }^{23}$

\section{Reagents}

\section{Alkaline solution}

a) $2 \%(\mathrm{w} / \mathrm{v})$ Sodium carbonate in $0.1 \mathrm{M} \mathrm{NaOH}$.

b) $1 \%(\mathrm{w} / \mathrm{v})$ Copper Sulphate

c) $2 \%$ Sodium Potassium tartrate

Working alkaline solution: $48 \mathrm{ml}$ of $\mathrm{A}+1 \mathrm{ml}$ of $\mathrm{B}+$ $1 \mathrm{ml}$ of $\mathrm{C}$

2. Stock std. Bovine Serum Albumin (BSA) - $1 \mathrm{mg} / \mathrm{ml}$

3. Working standard BSA $(1000 \mu \mathrm{g} / \mathrm{ml})$ diluted the stock 20 times.

4. Folin-Phenol reagent (ice-cold) diluted with equal amount of water at the time of use.

\section{Test Method:}

$0.1 \mathrm{ml}$ of supernatant was added to $0.9 \mathrm{ml} \mathrm{DDW}$ and $5 \mathrm{ml}$ of working alkaline reagent. The mixture was well mixed and then incubated at the temperature of the surrounding for $10 \mathrm{~min}$. Following this, $0.5 \mathrm{ml}$ Folin-phenol reagent was applied and hatched at the temperature of the surrounding for thirty minutes. The absorbance had been calculated against blank at $750 \mathrm{~nm}$. A standard and typical curve $(50-1000 \mu \mathrm{g})$ was then plotted accompanied by an estimate of the sample's protein content as $\mathrm{mg} / \mathrm{ml}^{23}$

\section{Statistically Done Analysis}

All of the findings were represented as an average \pm SEM and assessed by ANOVA which is One-way then by Tukey's multiple post-hoc evaluation study. A ' $P$ ' value of $<0.05$ has been recognized as statistically important. Graph Pad prism software analyzed data.

\section{RESULTS AND DISCUSSION}

\section{Elevated Plus Maze Test}

The result of the Baubinia variegata leaf excerpt and extract on elevated plus maze apparatus is shown in Figure 1. The Original Transferal Latency was conducted on the 14th day; i.e., acquisition trial, and no significant variation was found. Outcome are characterized as average $\pm \operatorname{SEM}(n=6), * P<0.05, * * P<0.01, * * *$ $P<0.001$ when ANOVA which is one way then by Tukey's tests compared with control group. In the leaf extract an increase in transmission latency was found and therefore nootropic activity was proven. The $400 \mathrm{mg} / \mathrm{kg}$ dosage of the Baubinia variegata leaf excerpt showed substantial improvement in the mice's transfer latency. This shows the action on the leaf by nootropic excerpt of Baubinia variegata.

\section{Step-through Passive avoidance paradigm}

The effect of Baubinia variegata leaf excerpt and extract on step-through passive avoidance paradigm is shown in Figure 2. The acquisition trial was performed and no substantial difference was observed. Outcomes are characterized as average of $\pm \operatorname{SEM}(n=6), * P<0.05, * * *$ $P<0.01, \cdots * 0.001$ when ANOVA which is one way then by Tukey's trial is applied to liken with control group. In the leaf extract a decrease in transmission latency was observed suggesting nootropic activity. The $400 \mathrm{mg} / \mathrm{kg}$ dosage of the Baubinia variegata leaf excerpt showed substantial reduction in the mice's transfer latency. This shows the possible nootropic activity of the leaf excerpt of Baubinia variegata.

\section{Morris water maze}

The effect of Baubinia variegata leaf extract on morris water maze is shown in Figure 3. Outcomes are characterized as average of $\pm \operatorname{SEM}(n=6),{ }^{*} P<0.05, * * P<0.01, * * * P<0.001$ 


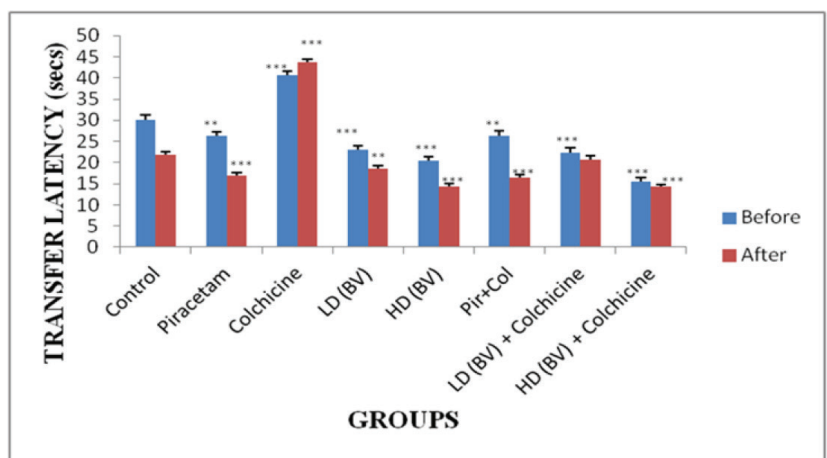

Figure 1: Impact of Bauhinia variegata extract and excerpt on Elevated plus maze.

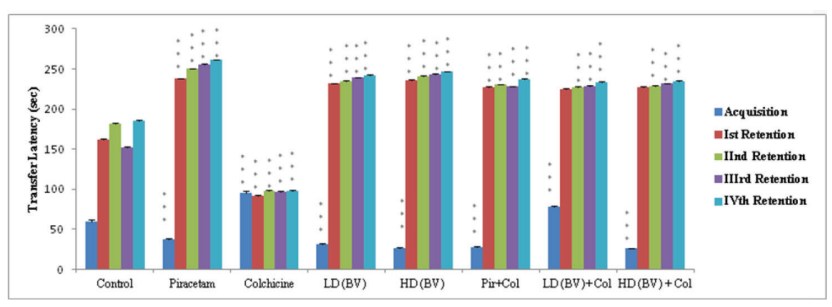

Figure 2: Effect of Bauhinia variegata extract on Passive avoidance paradigm.

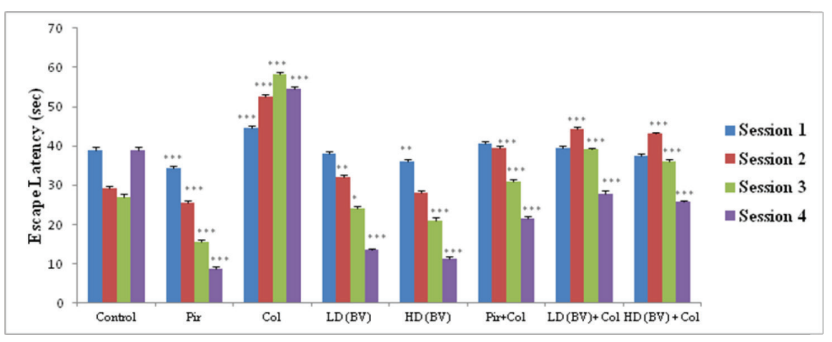

Figure 3: Impact of Bauhinia variegata excerpt and extract on Morris water maze.

when ANOVA which is one way then by Tukey's trial is applied to liken with control group. In the leaf extract an increase in escape latency was observed suggesting nootropic behavior. The $400 \mathrm{mg} / \mathrm{kg}$ dose of the Baubinia variegata leaf excerpt showed substantial improvements in the mice's escape latency. This shows the possible nootropic activity of the leaf extract Baubinia variegata.

\section{Actophotometer}

The effect of the Baubinia variegata leaf extract on an actophotometer is shown in Figure 4. Results are characterized as an average $\pm \operatorname{SEM}(n=6), * P<0.05$, ** $P<0.01$, *** $P<0.001$ when ANOVA which is one way then by Tukey's trial is applied to liken with control group. The leaf extract did not show any CNS depressant effect on mice.

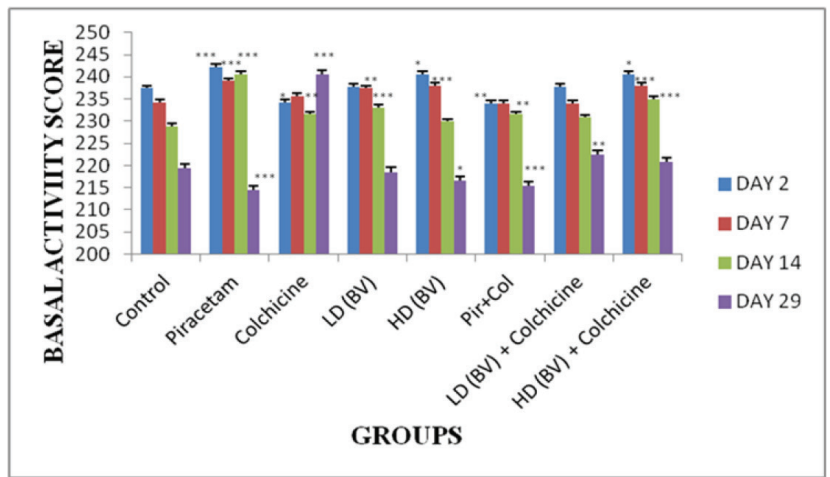

Figure 4: Impact of Bauhinia variegata extract on Actophotometer.

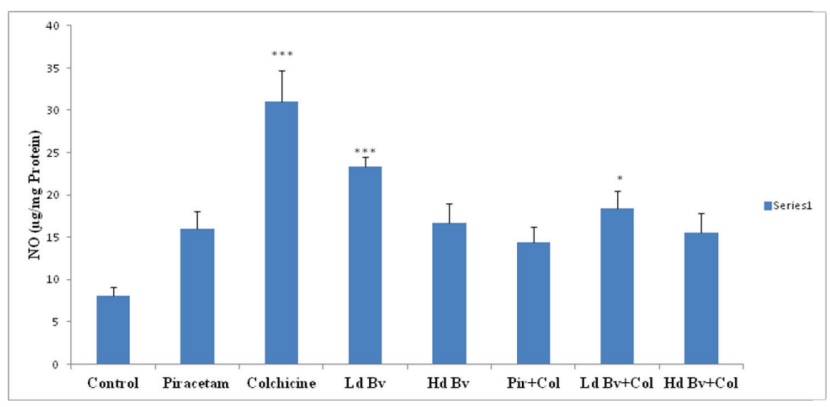

Figure 5: Impact of ethanolic extract and excerpt of Bauhinia variegata on NO level.

\section{Estimation of NO}

Figure 5 shows the effect of leaf extract of Baubinia variegata on NO level of mice's brain homogenate. The mice were sacrificed on the $29^{\text {th }}$ day, and the brain homogenate was prepared to predict NO level changes. Outcomes are denoted as MEAN $\pm \operatorname{SEM}(n=6)$, * $P<0.05, * *$ $P<0.01, * \% P<0.001$ when ANOVA which is one way then by Tukey 's tests likened with control group. In the leaf extract a large decrease in the amount of NO was observed, thus proving nootropic activity.

\section{Estimation of MDA}

The effect of Baubinia variegata leaf extract on MDA level of mice's brain homogenate is shown in Figure 6. The mice were sacrificed on the $29^{\text {th }}$ day, and the brain homogenate was prepared to predict improvements in the amount of MDA. Outcomes are denoted as average $\pm \operatorname{SEM}(n=6),{ }^{*} P<0.05, * * \quad P<0.01, * * * \quad P<0.001$ when ANOVA which is one way then by Tukey 's trial to liken with control set. A substantial decrease in the amount of MDA was found in the leaf extract and thus nootropic activity was confirmed. 


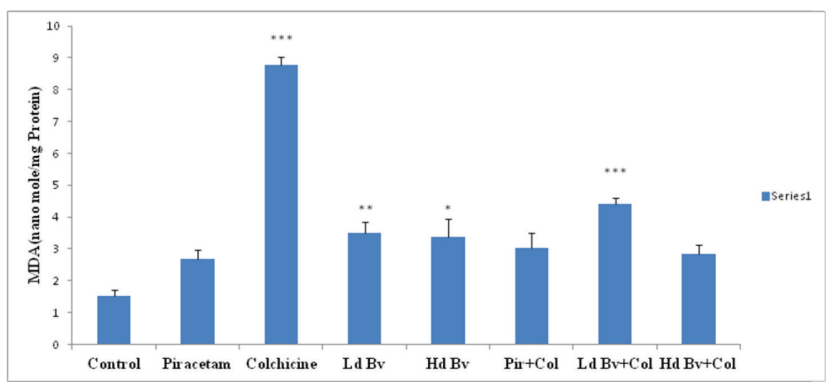

Figure 6: Impact of ethanolic excerpt and extract of Bauhinia variegata on MDA level.

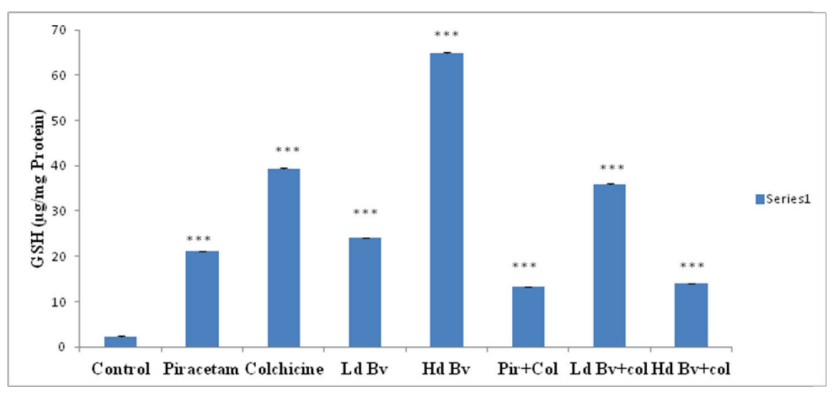

Figure 7: Impact of ethanolic excerpt and extract of Bauhinia variegata on GSH level.

\section{Estimation of GSH}

The effect of Baubinia variegata leaf extract on GSH level of mice's brain homogenate is shown in Figure 7. The mice were sacrificed on the 29th day and the brain homogenate was prepared to measure GSH level changes. Outcomes are denoted as MEAN $\pm \operatorname{SEM}(n=6)$, * $P<0.05$, $* 0<0.01, * * \quad P<0.001$ when one way ANOVA then by Tukey 's trial likened with control set. The leaf excerpt and extract showed a large increase in GSH level, thus proving nootropic activity.

\section{Estimation of AChE}

The effect of Baubinia variegata leaf extract on AChE level of mice's brain homogenate is shown in Figure 8. The mice were sacrificed on the $29^{\text {th }}$ day, and brain homogenate was prepared to estimate improvements in the amount of AChE. Outcomes are calculated as average $\pm \operatorname{SEM}(n=6), * P<0.05, * * P<0.01, * * * P<0.001$ when ANOVA which is one way then by Tukey 's trials and tests likened with control collection or group. In the leaf extract an increase in AChE level was observed suggesting nootropic activity.

Alzheimer's ailment and disease is a gradual onset neurodegenerative condition. A satisfactory drug for complete cure of Alzheimer's disease is yet to be developed in the allopathic system of medicine. Now we should look forward to treating this illness with the herbal medicines. In the current research, Baubinia variegata

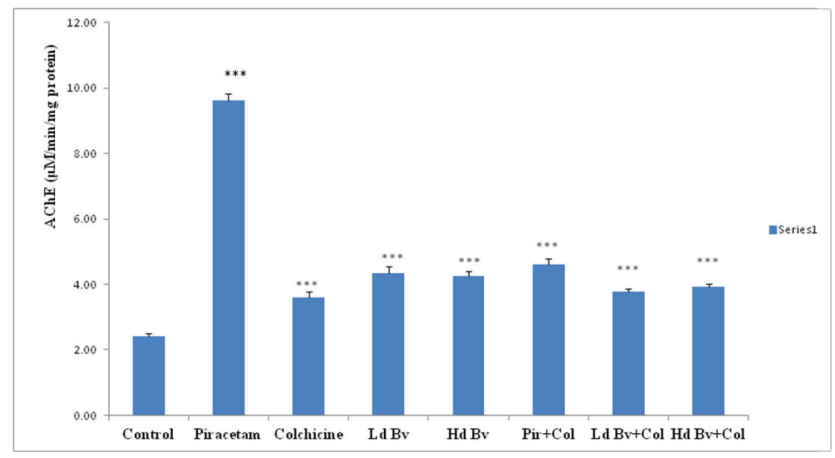

Figure 8: Consequence of ethanolic excerpt and extract of Bauhinia variegata on AChE level.

extract for 28 days was given orally which showed an improvement in mice's learning behavior. Throughout this analysis, the higher dose of Baubinia variegata extract (400 mg / kg ) significantly enhanced mice's memory as there was a decrease throughout Latency transferal in the case of raised plus maze system and increased Transfer Latency in the case of passive avoidance testing in contrast with the control set or group. In the case of morris water maze study, there was a decline in the latency Seepage as opposed to the control set. The locomotive operation indicated no symptoms of CNS distress. Baubinia variegata extract pretreatment for 28 days sheltered and sheltered the animals from the shortfalls of the memory generated by colchicine. These findings indicate the potential role of Baubinia variegata extract in neuroprotecting.

Reactive oxygen species (ROS) are the root cause of decline related to age in cognitive presentation that could be involved in elderly people developing Alzheimer's disease. Baubinia variegata has antioxidant properties. Baubinia variegata extract's neuroprotective activity is related to its antioxidant properties, due to which the susceptible neurons are subjected to less oxidative stress leading to reduced neuronal harm and enhanced neuronal function. The symptoms of dementia are impairment in neuronal transmission, decline in brain acetylcholine levels and neuronal circuit degeneration in the affected brain areas. From the present analysis it can be inferred that the Baubinia vareigata ethanolic excerpt and extract at a dosage of $400 \mathrm{mg} / \mathrm{kg}$ possesses nootropic activity comparable to the regular Piracetam medication. Pretreatment with Baubinia vareigata substantially reduced latency transferal in raised plus maze, improved latency transferal in passive avoidance study and decreased the escape latency in morris water maze. The Baubinia variegata ethanolic leaf extract decreased NO, MDA and increased the level of 
GSH, AChE. Hence the Baubinia vareigata ethanolic leaf extract has significant nootropic activity.

\section{ACKNOWLEDGEMENT}

We thank Shri Ram Murti Smarak, Department of Pharmacy, College of Engineering and Technology (Pharmacy), Bareilly, U.P. to provide chemicals and other facilities for conducting the study. The work is dedicated to my guide and co-guide.

\section{CONFLICT OF INTEREST}

The authors declare no conflict of interest.

\section{ABBREVIATIONS}

AChE: Acetyl cholinesterase; MDA: Malonyldialdehyde; GSH: Glutathione; ANOVA: Analysis of variance; IAEC: Institutional Animal Ethics Committee; CPCSEA: Committee for the Purpose of Control and Supervision of Experiments on Animals; rpm: Rotation Per Minute; BV: Baubinia variegata.

\section{REFERENCES}

1. Jivad N, Rabiei Z. A review study on medicinal plants used in the treatment of learning and memory impairments. Asian Pac J Trop Biomed. 2014;4(10):780-9. doi: 10.12980/APJTB.4.2014APJTB-2014-0412.

2. Patel VS, Jivani NP, Patel SB. Medicinal plants with potential nootropic activity: a review. Res J Pharm Biol Chem Sci. 2014;5:1-11.

3. Xu J, Rong S, Xie B, Sun Z, Zhang L, Wu H, Yao P, Zhang X, Zhang Y, Liu L. Rejuvenation of antioxidant and cholinergic systems contributes to the effect of procyanidins extracted from the lotus seedpod ameliorating memory impairment in cognitively impaired aged rats. Eur Neuropsychopharmacol. 2009;19(12):851-60. doi: 10.1016/j.euroneuro.2009.07.006, PMID 19716273.

4. Dhingra D, Parle M, Kulkarni SK. Memory enhancing activity of Glycyrrhiza glabra in mice. J Ethnopharmacol. 2004;91(2-3):361-5. doi: 10.1016/j. jep.2004.01.016, PMID 15120462.

5. Kulkarni PD, Ghaisas MM, Chivatbe ND, Sankpal PS. Memory enhancing activity of Cissampelos pariera in mice. Int J Pharm Pharm Sci. 2011;3:206-11.

6. Dr. Ramadas D, Dr. Ravishankar M, Dr. Shwetha S, Srinivas L. The learning and memory enhancing properties of Bacopa monnieri plant leaves protein: A systematic study in Wistar albino mice model system. Scholars Acad J Biosci. 2016;4:179-84.

7. Babawale OP, Taiye FR, Adetunji OS. Ethnobotanical survey of plants used as memory enhancer in three states of Southwestern Nigeria. J App Pharm Sci. 2016;6:209-14. doi: 10.7324/JAPS.2016.60931.

8. Phukan P, Bawari M, Sengupta M. Promising neuroprotective plants from North-East India. Int J Pharm Pharm Sci. 2015;7:28-39.

9. Patil JK, Patel MR, Sayyed HY, Patel AA, Pokal DM, Suryawanshi HP, et al. Pharmacognostic and phytochemical investigation of Bauhinia variegata (linn.) benth stem bark. Pharm Sci Monit. 2012;3:1-12.

10. Deswal G, Arora K. Ethnobotany and phytopharmacology of Bauhinia variegata. Int J Pharm Drug Anal. 2015;3:261-3.

11. Prashar Y, Kumar AS. Antiobesity activity of Bauhinia variegata Linn. in high fat diet induced obesity in female mice. Pharmacologyonline. 2010;2:1008-16.

12. Yadava RN, Reddy VMS. Anti-inflammatory activity of a novel flavonol glycoside from the Bauhinia variegata Linn. Nat Prod Res. 2003;17(3):165-9. doi: 10.1080/1478641031000104127.

13. Vogel HG. Drug discovery and evaluation pharmacological assays. Berlin, Heidelberg, Germany: Springer-Verlag; 2002. p. 620.

14. Chaudhary AK, Chauhan B. Memory enhancing activity of methanolic extract of Pterocarpus marsupium Roxb. Phytopharmacology. 2012;2:72-80.

15. Su J, Sripanidkulchai K, Wyss JM, Sripanidkulchai B. Curcuma comosa improves learning and memory function on ovariectomized rats in a long-term Morris water maze test. J Ethnopharmacol. 2010;130(1):70-5. doi: 10.1016/j. jep.2010.04.012.

16. Kulkarni SK. Handbook of experimental pharmacology. Vallabh Prakashan. $2007 ; 117$.

17. Marcocci L, Maguire JJ, Droy-Lefaix MT, Packer L. The nitric oxide-scavenging properties of Ginkgo biloba extract EGb 761. Biochem Biophys Res Commun. 1994;201(2):748-55. doi: 10.1006/bbrc.1994.1764, PMID 8003011.

18. Colado MI, O'Shea E, Granados R, Misra A, Murray TK, Green AR. A study of the neurotoxic effect of MDMA ('ecstasy') on 5-HT neurones in the brains of mothers and neonates following administration of the drug during pregnancy. Br J Pharmacol. 1997;121(4):827-33. doi: 10.1038/sj.bjp.0701201, PMID 9208155.

19. Ellman GL. Tissue sulfhydryl groups. Arch Biochem Biophys. 1959;82(1):70-7. doi: 10.1016/0003-9861(59)90090-6, PMID 13650640.

20. Ellman GL, Courtney KD, Andres Jr V, Feather-Stone RM. A new and rapid colorimetric determination of acetylcholinesterase activity. Biochem Pharmacol. 1961;7:88-95. doi: 10.1016/0006-2952(61)90145-9, PMID 13726518.

21. Joshi H, Parle M. Antiamnesic effects of Desmodium gangeticum in mice. Yakugaku Zasshi. 2006;126(9):795-804. doi: 10.1248/yakushi.126.795, PMID 16946593.

22. Pitchaimani $\mathrm{V}$, Arumugam $\mathrm{S}$, Thandavarayan RA, Thiyagarajan MK, Aiyalu R, Sreedhar R, et al. Nootropic activity of acetaminophen against colchicine induced cognitive impairment in mice. J Clin Biochem Nutr. 2012:1-4.

23. Lowry $\mathrm{OH}$, Rosebrough NJ, Farr AL, Randall RJ. Protein measurement with the Folin phenol reagent. J Biol Chem. 1951;193(1):265-75. doi: 10.1016/ S0021-9258(19)52451-6, PMID 14907713. 
PICTORIAL ABSTRACT

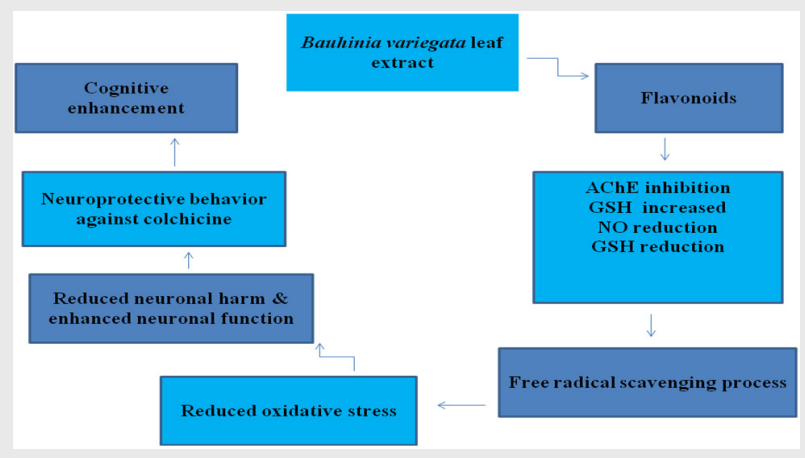

About Authors

\section{SUMMARY}

In Swiss albino mice the neuroprotective effect of Bauhinia variegata leaves was tested by a model of neurotoxicity caused by colchicine. Diverse behavioural and biochemical parameters have been measured in animals exposed to colchicine. Colchicine administration resulted in substantial memory deficits, which were also biochemically supported as the brain encountered increased oxidative stress and elevated acetylcholinesterase (AChE). In colchicine treated animals, pretreatment with ethanolic extract of Bauhinia variegata leaves significantly improved memory as well as decreased oxidative stress, $\mathrm{AChE}$ in the brain. The extract used has been shown to have neuroprotection as proof of improvement in the acetyl cholinesterase, lipid peroxidation, glutathione and protein neurological ranking. This may be due to the presence of flavonoids in Bauhinia variegata leaf.

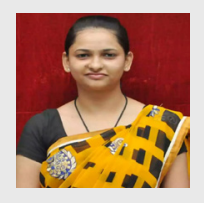

Mrs. Pragati Khare, M.Pharm., Ph.D. (persuing) Assistant Professor, Department of Pharmacology, Shri Ram Murti Smarak, College of Engineering and Technology, Bareilly, Uttar Pradesh, India. Published 40 research articles in National and International Journals. Guided 11 PG students.

Dr. Kamal Kishore, PhD, Associate Professor Department of Pharmacy, M.J.P. Rohilkhand University, Bareilly, Uttar Pradesh, INDIA.

Dr. Dinesh Kumar Sharma, PhD, Department of Pharmacy, Himalayan Institute of Pharmacy and Research, Dehradun, Uttarakhand, INDIA.

Cite this article: Khare P, Kishore K, Sharma DK. Neuroprotective Effect of Bauhinia variegata Leaf Extract against Colchicine: An Experimental Study on Cognitive Dysfunction and Biochemical Alterations in Mice. Indian J of Pharmaceutical Education and Research. 2021;55(3s):s798-s806. 